\title{
ANO1 Gene
}

National Cancer Institute

\section{Source}

National Cancer Institute. ANO1 Gene. NCI Thesaurus. Code C115173.

This gene plays a role in chloride transport. 